26. Ламехова Е.А. Методические основы факультатива «Использование растительных и животных объектов в организации биологических экскурсий» // Биологическое и экологическое образование: методология, теория, методика: сб. мат-лов XI междунар. методол. семинара. СПб.: Тесса, 2011. С. 90-93.
27. Ламехова Е.А., Палашкевич Г.А. Экологические убеждения будущих учителей биологии как основа активной профессиональной деятельности // Экология в средней и высшей школе: синтез науки и образования: мат-лы всерос. науч.-практ. конф. Челябинск: ЧГПУ, 2012. С. 120-125.

\title{
A SYSTEMATIC APPROACH TO SCHOOLCHILDREN'S ENVIRONMENTAL THINKING DEVELOPMENT AND PROSPECTIVE TEACHERS' TRAINING FOR THIS WORK ORGANIZATION
} (C) 2019

Lamekhova Elena Anatolyevna, candidate of pedagogical sciences, associate professor of General Biology and Physiology Department

South Ural State Humanitarian Pedagogical University (Chelyabinsk, Russian Federation)

Abstract. The following paper discusses one of the aspects of environmental education. It is related to the necessity to use a systematic approach for schoolchildren's environmental thinking development. The process of environmental thinking development is linked with environmental education implementation. For a long time, environmental education was considered as an integral part of biological education, but now an interdisciplinary approach to this work is considered. Different models of cognition are also considered, the recognition or denial of which influenced the nature of science development and the content of the educational process. Cognitive models in varying degrees, depending on specific conditions, determined the level and nature of ecological knowledge system development. A systematic approach for schoolchildren's environmental thinking development should be based on the main positions, which are the basis of cognitive models that act as paradigmatic methodological guidelines. The implementation of a systematic approach to environmental thinking development proceeds more successfully when using the practice-oriented approach, which lies at the basis of the lesson and students' extracurricular activities organization. The above mentioned approach can be now implemented in the form of project development. While working with students - prospective teachers, ecologization of disciplines is widely implemented.

Keywords: aspects of environmental education; schoolchildren's environmental thinking development; scientific knowledge system; knowledge models; paradigmatic methodological guidelines; practice-oriented approach; project development; ecologization; ecological knowledge system; interdisciplinary approach; lesson and students' extracurricular activities organization.

\section{ИСПОЛЬЗОВАНИЕ ОБРАЗОВАТЕЛЬНОЙ СРЕДЫ ЭКОЛОГИЧЕСКОГО ПАРКА В ШКОЛЬНЫХ ЗАНЯТИЯХ ПО БИОЛОГИИ (НА ПРИМЕРЕ ПОЛЯРНО-АЛЬПИЙСКОГО БОТАНИЧЕСКОГО САДА-ИНСТИТУТА ИМ. Н.А. АВРОРИНА КНЦ РАН)}

Митина Елена Гарисоновна, доктор педагогических наук, доцент, профессор кафедры естественных наук; научный консультант

Мурманский арктический государственный университет (2. Мурманск, Российская Федерация); Полярно-альпийский ботанический сад-институт им. Н.А. Аврорина Кольского научного иентра РАН (2. Апатиты, Мурманская область, Российская Федерачия)

Ищенко Анастасия Владимировна, младший научный сотрудник лаборатории медицинских и биологических технологий

Кольский научный центр РАН (2. Апатиты, Мурманская область, Российская Федераиия)

Аннотащиия. Статья посвящена поиску нестандартных путей обновления содержания школьного биологического образования. Формирование образовательной среды на базе экопарков рассматривается как инновационный подход в данном направлении, отвечающий запросам современного общества и находящийся в русле основных тенденций его развития. Основываясь на данных, полученных по результатам опроса практикующих педагогов-биологов, в статье дается анализ целесообразности привлечения образовательных возможностей экологических парков для школьных занятий. В соответствии с его результатами, а также с установленными для средних общеобразовательных школ структурой и содержанием курса биологии, была разработана авторская программа «Природа Кольского края». Содержание программы согласовано с разделами школьной биологии: «Биология - наука о живой природе», «Клеточное строение организмов», «Царство растения», «Многообразие животного мира» и «Экосистемы» - и является дополнением к программной линии В.В. Пасечника «Биология 6-9 класс». На базе экопарка Полярно-альпийского ботанического сада-института им. Н.А. Аврорина КНЦ РАН (г. Кировск Мурманской обл.) проведена оценка эффективности авторской образовательной программы «Природа Кольского края» и показано, что при ее использовании в качестве дополнения к основному школьному курсу биологии уровень освоения его обучающимися существенно возрастает.

Ключевые слова: общеобразовательная школа; биологическое образование; содержание школьной биологии; процесс обучения биологии; формы обучения; результаты обучения; образовательная среда; средовой подход; ботанический сад; экологический парк; авторские образовательные программы. 


\section{Введение}

Повышение эффективности биологического образования подрастающего поколения в настоящее время является одной из важнейших задач, стоящих перед педагогами $[1$, c. 26]. Возросший на рубеже XX и XXI вв. интерес к этой теме обусловлен как преобразованиями в политической, социально-экономической и культурной жизни страны, так и сменой вектора ценностных ориентаций мирового сообщества в целом. Небывалое развитие биотехнологий, благодаря которому XXI век принято сейчас называть «веком биологии», привело к необходимости коренного реформирования системы биологического образования в целом [2, с. 18].

Идея использования просветительского потенциала экологических парков в данном направлении нашла отражение в «Стратегии устойчивого развития», принятой на Международной конференции ООН в 1992 г. Одним из ключевых положений Стратегии является развитие ботанических садов и экопарков как образовательных центров, что означает существенное расширение сферы их деятельности и необходимость привлечения к ней педагогов, психологов и социологов [3, с. 474].

Актуальность настоящей работы обусловлена противоречиями между:

- выраженным общественным интересом к использованию экопарков в качестве образовательных центров и поверхностным характером существующих представлений о возможностях формирования образовательной среды на их базе;

- необходимостью обновления содержания школьных курсов биологии и отсутствием научного обоснования возможностей освоения их отдельных разделов в условиях образовательной среды экопарков;

- высоким образовательным потенциалом экологических парков и низкой заинтересованностью в сотрудничестве с ними учреждений общего образования.

На основе выявленных противоречий была сформулирована проблема исследования, которая заключается в необходимости оценки потенциала образовательной среды экологических парков как основы системного изучения биологических объектов и формирования у обучающихся целостной картины мира.

\section{Гипотеза исследования}

Повышение эффективности освоения обучающимися содержания школьного курса биологии в условиях образовательной среды экологических парков возможно при условиях:

- углубленного изучения и систематизации существующих представлений о средовом подходе к биологическому образованию;

- применения средового подхода к описанию экопарков как инновационного направления деятельности ботанических садов;

- проектирования курсов для обучения биологии в условиях экопарков с учетом структуры и содержания биологических программ, установленных для средних общеобразовательных школ;

- разработки, экспериментальной проверки, оценки эффективности обучения школьников и подтверждения достоверности полученных результатов.

Цель исследования: теоретически обосновать и экспериментально проверить эффективность усвоения курса биологии обучающимися 6-7 классов в условиях образовательной среды экопарка Полярно-альпийского ботанического сада-института (далее - ПАБСИ).
Для достижения этой цели были поставлены следующие задачи:

1) обобщить данные литературы о методологии средового подхода в биологическом образовании;

2) подготовить характеристику экопарка ПАБСИ как разновидности образовательной среды;

3) определить содержание обучения и разработать программу, соответствующую содержанию школьного курса биологии 6-7 классов для экопарка ПАБСИ;

4) сформулировать критерии и подобрать необходимый инструментарий для оценки результатов обучения школьников биологии в образовательной среде экологического парка ПАБСИ.

Объектом исследования является экопарк как образовательная среда, а его предметом - эффективность обучения биологии школьников в условиях экопарка ПАБСИ.

Для разработки принципов формирования образовательной среды на базе экологических парков необходимо подробно рассмотреть понятия «образование», «среда», «средовой подход», «образовательная среда» и «экологический парк».

В наиболее широком смысле образование можно рассматривать как гармоническое взаимодействие трех основных педагогических категорий - обучение, воспитание и развитие [4, с. 937].

Термин «среда» отражает взаимосвязи условий, обусловливающих развитие индивида. В данном случае предполагается присутствие человека в среде, взаимодействие и взаимовлияние субъекта и его окружения [5, с. 16].

Понятие «средовой подход» подразумевает совокупность теоретических положений, определяющих значение составляющих его компонентов в контексте идей изучения, проектирования, организации и оптимизации среды, а также продуцирования результата ее влияния на личность [6, с. 21].

Понятие «образовательная среда» (далее - ОС), согласно требованиям ФГОС, трактуется как сбалансированное сочетание внешних и внутренних условий и факторов, существенно влияющих на образовательный процесс [7, с. 26].

В современной литературе под экопарком понимается достаточно обширная особо охраняемая природная территория регионального значения, обязательно совмещающая в себе естественную или искусственно созданную лесопарковую зону, коллекции растений, виварий, а также специальное пространство для образования и творчества $[8$, с. 16].

Экологический парк ПАБСИ сочетает в себе естественную (лесную) и облагороженную (парковую) территории. В последние годы на базе этих территорий в ПАБСИ активно развивается деятельность в направлениях экологического просвещения и образования, а также экологической терапии [9, с. 291].

На протяжении последних 8 лет в ПАБСИ был разработан ряд образовательных и коррекционных программ, в том числе.: «Путешествие в мир северной природы» (М.П. Советова, Е.Г. Митина, О.Б. Гонтарь), «В царстве растений» (Е.Г. Митина, М.П. Советова), «Гарденотерапия для детей и подростков» (О.Б. Гонтарь, Е.А. Святковская, И.В. Калашникова, Н.Н. Тростенюк, О.Ю. Носатенко, Е.П. Шлапак, 
В.К. Жиров), которые используются общеобразовательными средними школами и специализированными социальными учреждениями Мурманской области $[10$, с. 96$]$.

С октября 2017 года на базе ПАБСИ проводятся занятия клуба юных натуралистов «Полярные юннаты», в рамках которых реализуется комплексная программа по биологии «Природа Кольского края» для обучающихся 6-7 классов. Деятельность этого клуба послужила основой нашей работы.

На констатирующем этапе исследования было опрошено 90\% учителей, преподающих биологию в общеобразовательных средних школах г. Апатиты Мурманской области.

Анализ полученных данных позволил заключить, что изучение биологии в условиях образовательной среды экологического парка с привлечением местного материала открывает широкие возможности фор- мирования не только знаний и умений, но и ценностных ориентаций школьников.

В ходе исследования было установлено, что 50\% респондентов включают в содержание своих уроков по биологии местный материал, получая опыт организации выездных познавательных экскурсий и прогулок по экопарку ПАБСИ. Остальные 50\% констатировали отсутствие необходимости этих мероприятий в процессе преподавания своей дисциплины, отметив, что их проведение в учебное время не представляется возможным [11, с. 65].

На формирующем этапе исследования разрабатывалось содержание курса обучения биологии школьников на базе экопарка в соответствии с установленными для средних общеобразовательных школ структурой и содержанием программ по биологии $[12$, c. 49] (рис. 1)

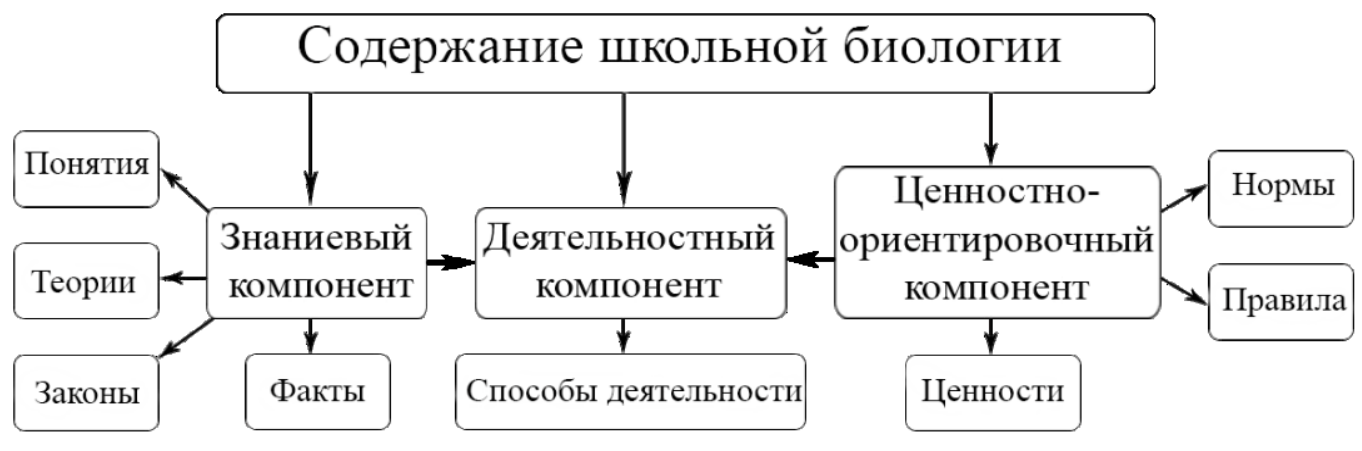

Рисунок 1 - Содержание и структура программы школьной биологии

Основным критерием отбора компонентов содержания разрабатываемого курса, кроме его соответствия действующим стандартам [13, с. 17], была обеспеченность ресурсами образовательной среды ПАБСИ (рис. 2).

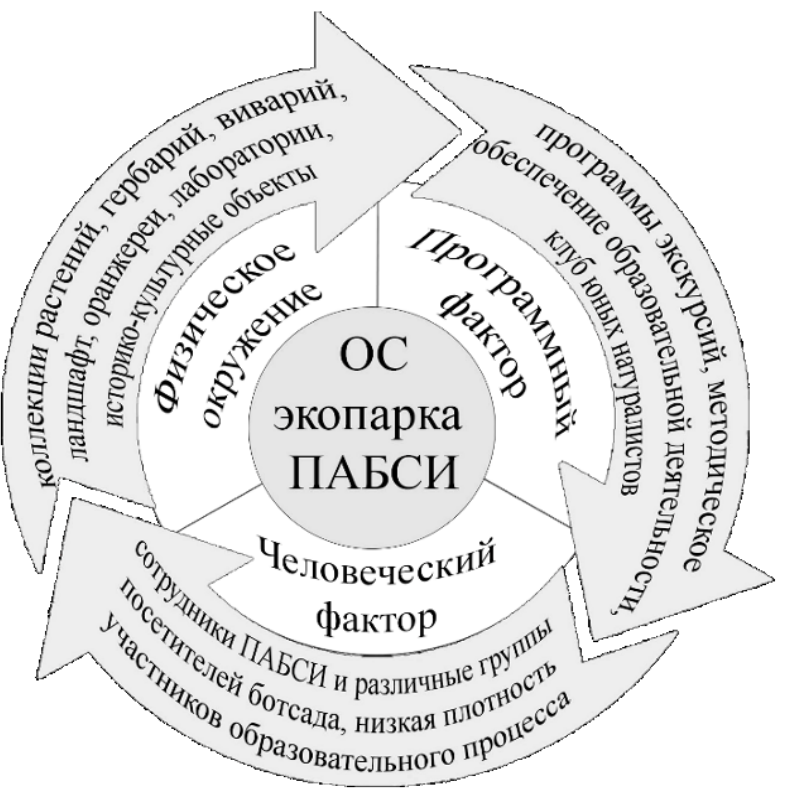

Рисунок 2 - Компоненты образовательной среды экопарка ПАБСИ

Содержание обучения было реализовано в рамках авторской учебной программы «Природа Кольского края», ориентированной на укрепление связи личного опыта обучающихся с изучаемым материалом путем формирования основных представлений о природных особенностях родного края в условиях ОС экопарка ПАБСИ (рис. 3).
Разработанная программа является дополнением к программной линии В.В. Пасечника «Биология 6-9 класс» [14, с. 3-5] и корреспондируется с ее разделами: «Биология - наука о живой природе» $[15$, с. 8 10], «Клеточное строение организмов» [15, с. 30-45], «Царство растения» [15, с. 88-132], «Многообразие животного мира» [16, с. 12-183], «Экосистемы» [16, c. $268-277 ; 17$, с. $188-197]$.

В таблице сравнивается тематическое планирование программы «Природа Кольского края» и программы В.В. Пасечника на примере раздела «Экосистемы» (табл. 1).

Экспериментальная группа школьников (10 человек) изучала школьный курс биологии и занималась по программе «Природа Кольского края», контрольная (30 человек) изучала биологию только в рамках школьного курса.

Для оценки актуального уровня освоения указанных разделов содержания школьной биологии всем участникам до начала эксперимента предлагалась контрольная работа, состоящая из 12 заданий, разделенных на три блока (по четыре задания в каждом блоке).

Задания всех трех блоков («Водные экосистемы», «Лесные экосистемы» и «Тундровые экосистемы») были направлены не только на оценку знаний обучающихся об экосистемах Кольского п-ова, но и на оценку их способности решать биологические задачи, умения обосновывать свою позицию, давать развернутые и обоснованные ответы на поставленные вопросы, а также на выявление ценностного отношения школьников к обитателям экосистем.

В качестве примера приведем одно из заданий из блока «Тундровые экосистемы» (рис. 4). 


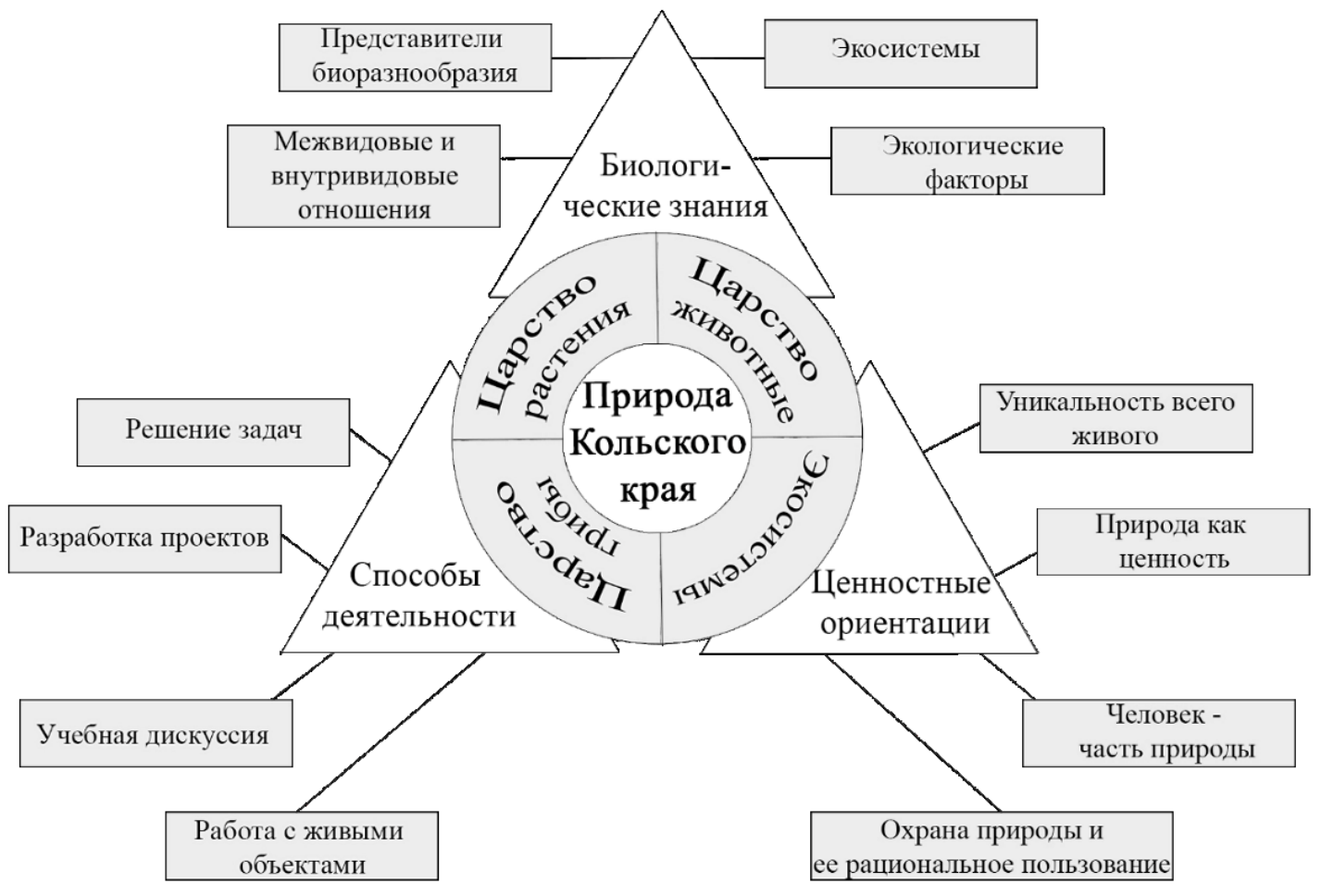

Рисунок 3 - Содержание программы «Природа Кольского края»

Таблица 1 - Согласованность тематического планирования программ «Природа Кольского края» и «Биология 6-7 класс» В.В. Пасечника

\begin{tabular}{|c|c|c|c|}
\hline $\begin{array}{l}\text { «Природа Кольского края» } \\
\text { (всего } 19 \text { часов) }\end{array}$ & & \multicolumn{2}{|c|}{$\begin{array}{l}\text { «Линия жизни» В.В. Пасечник. «Биология 6-7 класс» } \\
\text { (всего } 15 \text { часов) }\end{array}$} \\
\hline \multicolumn{4}{|c|}{ Раздел «Экосистемы» } \\
\hline Темы & Часы & Темы & Часы \\
\hline Экосистема осеннего леса: поздняя осень & 2 & Экосистема & 1 \\
\hline $\begin{array}{l}\text { Водные экосистемы } \\
\text { Кольского полуострова }\end{array}$ & 2 & $\begin{array}{l}\text { Среда обитания организмов. } \\
\text { Экологические факторы }\end{array}$ & 1 \\
\hline Тундровые экосистемы: «Книга тундры» & 2 & \multirow{2}{*}{ Искусственные экосистемы } & \multirow{2}{*}{1} \\
\hline Экосистема города Апатиты & 2 & & \\
\hline
\end{tabular}

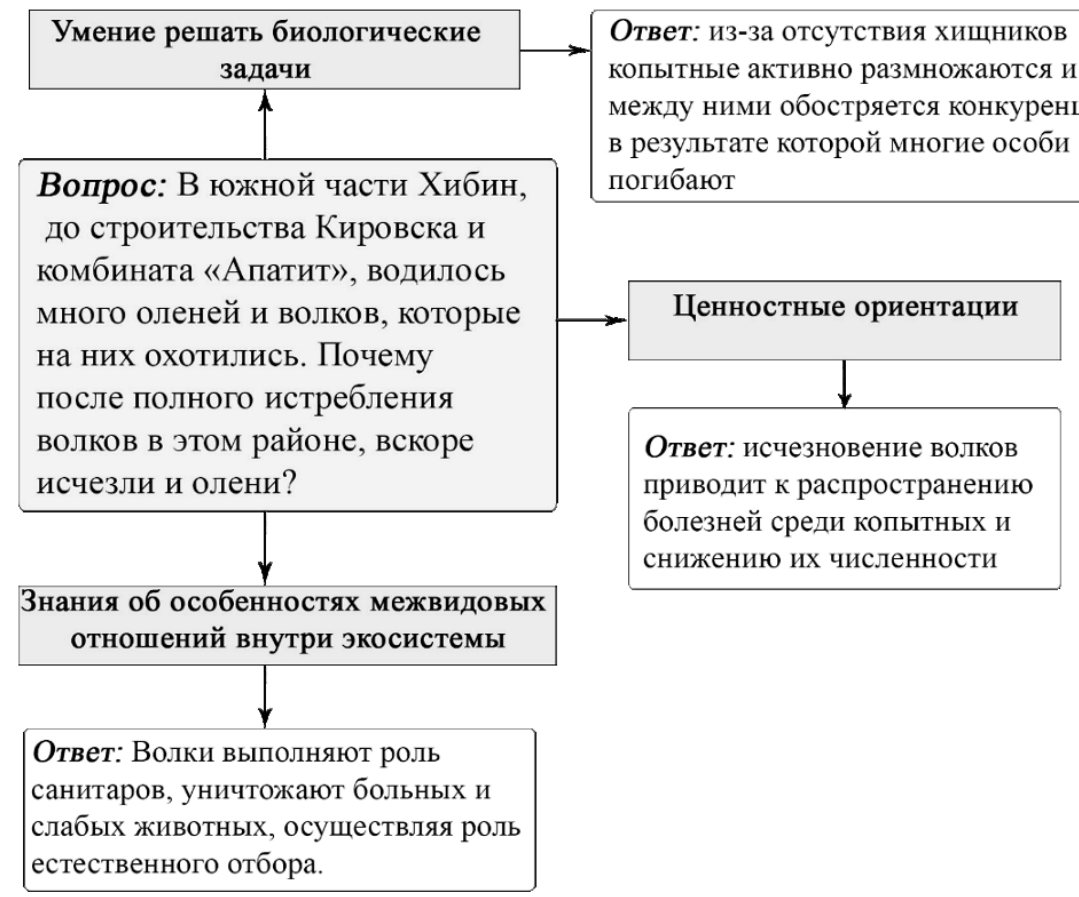

Рисунок 4 - Пример задания контрольной работы

для оценки актуального уровня освоения школьной биологии. Блок «Тундровые экосистемы» 
За основу разработки контрольно-измерительных материалов (КИМов) была взята структура КИМов Единого государственного экзамена (ЕГЭ) [18, с. 13]. Система критериев оценки представлена в табл. 2.

Таблица 2 - Критерии оценки ответов на вопросы контрольной работы по теме «Природа Кольского края»

\begin{tabular}{|c|l|}
\hline $\begin{array}{c}\text { Оценка, } \\
\text { баллы }\end{array}$ & \multicolumn{1}{|c|}{ Критерии } \\
\hline 3 & $\begin{array}{l}\text { ответ включает в себя все три элемента } \\
\text { и не содержит биологических ошибок }\end{array}$ \\
\hline 2 & $\begin{array}{l}\text { ответ включает в себя только два элемен- } \\
\text { та, но при этом не содержит биологиче- } \\
\text { ских ошибок }\end{array}$ \\
\cline { 2 - 2 } & $\begin{array}{l}\text { ответ включает в себя все три элемента, } \\
\text { но содержит незначительные биологиче- } \\
\text { ские ошибки }\end{array}$ \\
\hline 1 & $\begin{array}{l}\text { ответ включает в себя только один } \\
\text { из указанных элементов и не содержит } \\
\text { биологических ошибок }\end{array}$ \\
\cline { 2 - 2 } & $\begin{array}{l}\text { ответ включает в себя два из указанных } \\
\text { элементов и содержит негрубые биоло- } \\
\text { гические ошибки }\end{array}$ \\
\hline 0 & $\begin{array}{l}\text { все случаи решения, для которых оценка } \\
\text { по вышеуказанным критериям невозможна }\end{array}$ \\
\hline
\end{tabular}

Примечание. Максимальная оценка за работу 36 баллов (по 3 балла за каждый из 12 вопросов).

Для определения уровня сформированности знаний по биологии у обучающихся нами были определены следующие уровни: 0-25\% выполнения - низкий уровень, 26-50\% - уровень ниже среднего, 51$75 \%$ - средний уровень, 76-100\% - высокий уровень.

Оценка полученных результатов производилась по формуле: $O=\Phi / \Pi \times 100 \%$, где $O$ - оценка успеваемости (обученности, продуктивности); $\Phi$ - фактический объем усвоенных знаний, умений, ценностных ориентаций; П - полный объем знаний, умений и ценностных ориентаций, предложенных для усвоения [19, с. 210].

Достоверность различий между контрольной и экспериментальной группами по используемым показателям оценивалась по t-критерию Стьюдента с использованием стандартного набора статических программ для независимых выборок [20, с. 64]. Обсуждались только различия, достоверные на $5 \%$ уровне значимости.

Результаты оценки стартового уровня освоения школьной программы биологического образования по разделам: «Биология - наука о живой природе», «Клеточное строение организмов», «Царство растения», «Многообразие животного мира», «Экосистемы» - в рамках темы «Природа Кольского края» контрольной группы школьников показала следующие результаты (рис. 5).

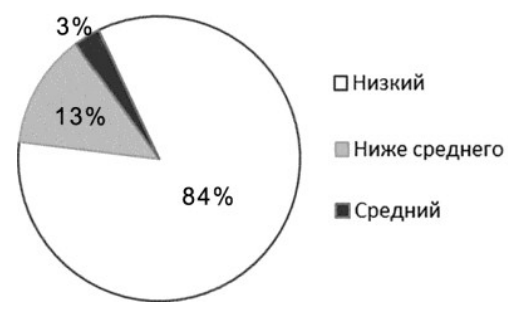

Рисунок 5 - Уровень освоения школьной программы по биологии участников контрольной группы до начала эксперимента

Как видно, средний уровень освоения школьной программы по биологии продемонстрировали только
$3 \%$, школьников контрольной группы, ниже среднего - $13 \%$, а оставшиеся $84 \%$ - низкий уровень по вышеуказанным разделам.

Результаты оценки знаний по биологии участников экспериментальной группы до начала эксперимента представлены ниже (рис. 6).

Из рис. 6 следует, что до начала эксперимента у $20 \%$ участников экспериментальной группы уровень освоения программы школьной биологии был ниже среднего, у остальных $80 \%$ - низкий, а средний уровень не продемонстрировал никто из них.

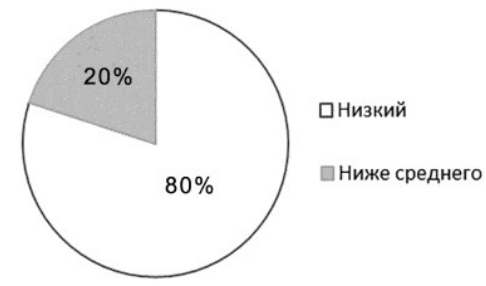

Рисунок 6 - Уровень освоения школьной программы по биологии участников экспериментальной группы до начала эксперимента

Ниже приведены результаты сравнения данных, представленных на рисунках 4 и 5 (рис. 7).

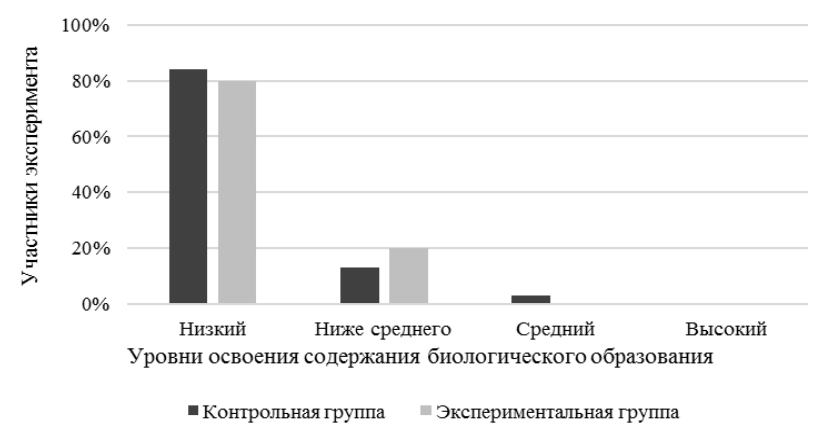

Рисунок 7 - Сравнение уровней освоения школьной программы по биологии участников контрольной и экспериментальной группы до начала эксперимента

Судя по рисунку 7, контрольная и экспериментальная группы практически не различались по уровню освоения школьной программы по биологии, в связи с чем использование второй для дальнейшего проведения эксперимента было корректным.

Результаты оценки уровня освоения школьной программы по биологии участниками контрольной группы по окончании эксперимента представлены на рисунке (рис. 8).

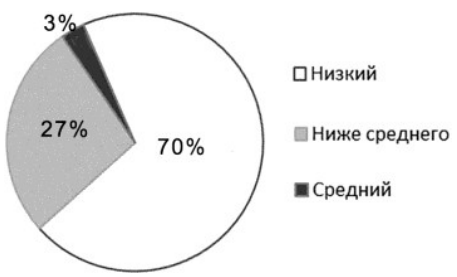

Рисунок 8 - Уровень освоения школьной программы по биологии участников контрольной группы по окончании эксперимента

Как следует из рис. 8, через 2 месяца, в течение которых проводился эксперимент, только у $3 \%$ участников контрольной группы был зарегистрирован средний уровень освоения указанных тем школьной программы по биологии, уровень ниже среднего $7 \%$, а знания остальных испытуемых соответствовали самым низким показателям.

В экспериментальной группе по окончании эксперимента $100 \%$ участников экспериментальной 
группы показали средний уровень освоения содержания школьной биологии, умения давать развернутые ответы на поставленные вопросы и сформированные ценностные ориентации.

На рис. 9 в графической форме представлены результаты сравнительной оценки уровня освоения школьной программы по биологии участниками контрольной и экспериментальной групп по окончании эксперимента (рис. 9).

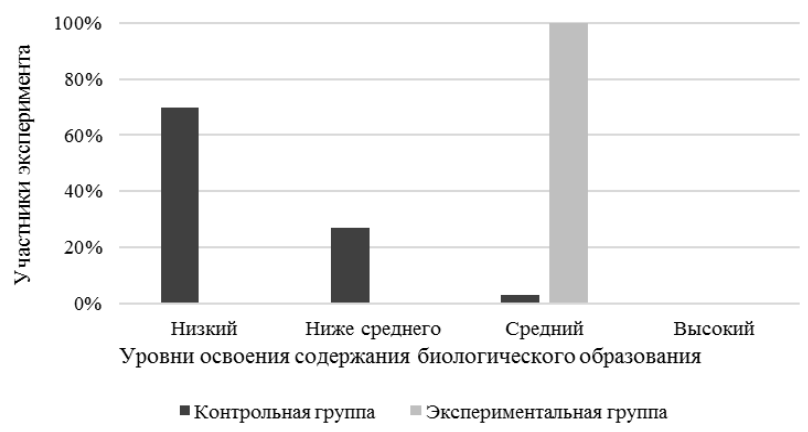

Рисунок 9 - Сравнение уровней освоения школьной программы по биологии участников контрольной и экспериментальной групп по окончании эксперимента

Сравнение результатов контрольной и экспериментальной групп по статистическому методу «tкритерий Стьюдента» для независимых выборок показало, что полученное эмпирическое значение $\mathrm{t}$ $(11,3)$ находится в зоне значимости.

Принимая во внимание непродолжительность эксперимента - обучение школьников в условиях образовательной среды экологического парка ПАБСИ происходило на протяжении всего двух месяцев - его результат можно охарактеризовать как положительный.

Полученные данные подтверждают возможность использования экологического парка ПАБСИ в качестве образовательной среды для формирования знаний школьников о природе родного края, умения применять полученные знания на практике и становления у них ценностных ориентаций.

\section{Выводы исследования \\ и перспективы дальнейших изысканий данного направления}

Результаты настоящего исследования свидетельствуют о повышении эффективности занятий по биологии со школьниками 6-7 классов при использовании потенциала образовательной среды экологических парков.

Как показала апробация оригинальной программы «Природа Кольского края», ориентированной на проведение школьных занятий по биологии на базе экологического парка ПАБСИ, условия его образовательной среды способствуют заметному повышению уровня освоения обучающимися содержания программы школьной биологии по разделам «Биология - наука о живой природе», «Клеточное строение организмов», «Царство растения», «Многообразие животного мира» и «Экосистемы».

Образовательная среда и обусловленный ее возможностями образовательный потенциал экологических парков являются важными факторами развития биологических знаний, умений применять полученные знания на практике, навыков решения биологических задач и формирования ценностных ориентаций у обучающихся 6-7 классов.

Проектирование содержания программ школьного обучения биологии, направленных на реализацию в условиях экологических парков, будет способствовать дальнейшему развитию интеграции общего и дополнительного образования в области естественных предметов.

\section{Список литературы:}

1. Голикова Т.В., Иванова Н.В., Пакулова В.М. Теоретические вопросы методики обучения биологии: учебное пособие. Красноярск: Краснояр. гос. пед. ун-т им. В.П. Астафьева, 2013. 264 с.

2. Жумагулова К.А. Обновление содержания биологического образования // Педагогика и психология образования. 2012. № 3. С. 17-20.

3. Доклад Конференции Организации объединенных наций по окружающей среде и развитию // Резолюции, принятые на конференции (3-14 июня 1992 г.). Т. 1. Нью-Йорк: Изд-во Организации объединенных наций, 1993. 528 с.

4. Исмаилова 3.К., Байбаева М.Х., Сапаров А.Б. Основные категории педагогики - развитие, воспитание, обучение, образование // Молодой ученый. 2015. № 8. С. 937-940.

5. Митина Е.Г. Эколого-образовательная среда региона как фактор развития системы методической подготовки студентов-биологов: монография. Мурманск: МГГУ, 2013. 156 с.

6. Мануйлов Ю.С. Концептуальные основы средового подхода в воспитании // Вестник Костромского государственного университета. Сер.: Педагогика. Психология. Социокинетика. 2008. № 14 (4). С. 21-27.

7. Коротенков Ю.Г. Информационная образовательная среда основной школы. М.: Академия Ай-ти, 2017. 243 c.

8. Голиченков А.К. Экологическое право России: словарь юридических терминов: учеб. пособие для вузов. М.: Издательский Дом «Городец», 2008. 448 с.

9. Марус Е.А., Митина Е.Г. Образовательный потенциал ботанических садов в условиях Арктики: к постановке проблемы // Международный студенческий научный вестник. 2016. № 4 (3). С. 291-292.

10. Жиров В.К., Гонтарь О.Б., Святковская Е.А., Советова М.П., Мазуренко И.Н. Новое в просветительской деятельности Полярно-альпийского ботанического сада-института // Вестник КНЦ РАН. 2010. № 3. C. 95-100.

11. Жирова А.В., Митина Е.Г. Возможности развития биологических знаний школьников в условиях экопарка // Биологическое и экологическое образование в школе и вузе: теория, методика, практика: сб. ст. междунар. науч.-практ. конф. (14-17 ноября 2017 г.). Вып. 15 (2), г. Санкт-Петербург / отв. ред. Н.Д. Андреева. СПб.: Свое издательство, 2017. С. 64-67.

12. Андреева Н.Д., Азизова И.Ю., Малиновская Н.В. Новые концептуальные обучения биологии в общеобразовательной школе в условиях ФГОС: учебнометодическое пособие. СПб.: Изд-во «Свое издательство», 2014. 219 с.

13. Федеральный государственный образовательный стандарт основного общего образования. 7-е изд. М.: Просвещение, 2018. 60 с.

14. Рабочие программы. Биология. 5-9 классы: учебно-методическое пособие / сост. Г.М. Пальдяева. М.: Дрофа, 2016. 382 с.

15. Пасечник В.В. Биология. 5 класс. Бактерии, грибы, растения: учебник. М.: Дрофа, 2013. $141 \mathrm{c.}$

16. Латюшин В.В., Шапкин В.А. Биология. Животные. 7 класс: учеб. для общеобразоват. учеб. заведений. М.: Дрофа, 2000. 302 с.

17. Пасечник В.В. Биология. Многообразие покрытосеменных растений. 6 класс: учебник. М.: Дрофа, 2014. 207 c. 
18. Калинова Г.С., Никишова Е.А., Петросова Р.А. Биология. Решение заданий повышенного и высокого уровня сложности. Как получить максимальный балл на ЕГЭ. М.: Изд-во «Интеллект-центр», 2016. 128 с.

19. Лаврентьев Г.В., Лаврентьева Н.Б., Неудахина Н.А. Инновационные обучающие технологии в

\section{ECOLOGICAL PARKS EDUCATIONAL ENVIRONMENT USAGE AT BIOLOGY LESSONS IN SCHOOLS (ON THE EXAMPLE OF N.A. AVRORIN POLAR-ALPINE BOTANICAL GARDEN-INSTITUTE)} (C) 2019

Mitina Elena Garisonovna, doctor of pedagogical sciences, professor of Natural Sciences Department; research consultant Murmansk Arctic State University (Murmansk, Russian Federation); N.A. Avrorin Polar-Alpine Botanical GardenInstitute of Kola Scientific Centre of Russian Academy of Sciences (Apatity, Murmansk Region, Russian Federation) Ishchenko Anastasia Vladimirovna, junior researcher of Medical and Biological Technologies Laboratory Kola Scientific Center of Russian Academy of Sciences (Apatity, Murmansk Region, Russian Federation)

Abstract. The paper is devoted to the search of alternative ways to update school Biology curriculum. Creation of educational environment at the premises of ecological parks is considered to be an innovative and promising prospective approach that meets contemporary demands and follows central developmental trends of society. Based on the results of practicing Biology teachers' poll, we give an expediency analysis of engaging ecological parks educational opportunities for school lessons. According to available data as well as based on the structure and the content of biological education prescribed for secondary school, the author's program «Kola Land nature» has been developed. The content of our program is an addition to the General program line «Biology for 6-9 classes» created by V.V. Pasetchnik, it matches the themes of a school Biology course: «Biology as a science of vital nature», «Cellular structure of organisms», «Plant kingdom», «Diversity of fauna», «Ecosystems». Effectiveness evaluation of the author's educational program «Kola Land nature» was realized in the ecological park of N.A. Avrorin Polar Alpine Botanical Garden \& Institute. The obtained data confirm that the program usage as an addition to the basic school Biology course improves the level of its mastering by students.

Keywords: secondary school; biological education; school Biology content; Biology learning process; educational forms; learning outcomes; educational environment; environmental approach; botanical garden; ecological park; author's educational programs.

УДК 371

DOI 10.24411/2309-4370-2019-12305

Статья поступила в редакцию 28.02.2019

\section{ГЛОБАЛЬНАЯ ЦЕЛЬ МЕДИАОБРАЗОВАНИЯ В УСЛОВИЯХ ИНФОРМАЦИОННОГО ОБЩЕСТВА}

(C) 2019

Позднякова Оксана Константиновна, доктор педагогических наук, профессор,

член-корреспондент Российской академии образования, профессор кафедры педагогики и психологии

Самарский государственный соииально-педагогический университет (2. Самара, Российская Федераиия)

Крылова Елена Леонидовна, директор

Филиал «Государственная телевизионная и радиовещательная компания "Самара"» Всероссийской государственной телевизионной и радиовещательной компании (2. Самара, Российская Федераиия)

Аннотация. В статье актуализируется проблема медиаобразования в условиях современного российского общества, позволяющего овладевать умениями и навыками эффективной работы с информацией. Обосновывается, что медиаобразование способствует подготовке прежде всего молодого поколения к жизни в современных условиях, к эффективному восприятию информации и ее осмыслению, к осознанию воздействия различных видов информации на психику, а также к овладению современными техническими средствами невербальной коммуникации. Подчеркивается роль медиаобразования в превращении молодежи в креативных создателей собственного контента, развитие их как гармоничной личности - развитие эмоций, интеллекта, формирование мировоззрения, приобщение к нравственным ценностям. Обозначается роль средств массовой информации в формировании медиакультуры и информационной грамотность населения в целом и детей и молодежи в особенности. Обосновывается, что глобальной целью медиаобразования в условиях информационного общества является построение идеологического фундамента общества. Аргументируется, что одной из важных задач, направленных на достижение глобальной цели медиаобразования является формирование патриотизма, как одной из базовых российских ценностей. Обозначается взаимосвязь патриотического воспитания и медиаобразовательного процесса. Приводится содержание мультимедийного патриотического медиаобразовательного проекта (фестиваля) федерального масштаба Первый Всероссийский медиаконкурс «Русский космос», способствующее развитию личности с помощью и на материале средств массовой информации, получению историко-краеведческих знаний и приобщению к величайшим страницам истории родной страны. Делается вывод о важной роли медиаобразования в подготовке детей, подростков, юношей к жизни в новом технологическом укладе, к работе в условиях многополярности виртуального мира и бесконечного потока разнонаправленной информации.

Ключевые слова: медиаобразование; информационное общество; цель; задачи; информация; информационная грамотность; медиакультура; медиапространство; средства массовой информации; глобальная сеть; медиасреда; медиапродукт; патриотизм; патриотическое воспитание; коммуникативная стратегия. 